\title{
Value of traditional foods in meeting macro- and micronutrient needs: the wild plant connection
}

\author{
Louis E. Grivetti ${ }^{1}$ and Britta M. Ogle ${ }^{2}$ \\ ${ }^{1}$ Department of Nutrition, University of California, 1 Peter J. Shields Avenue, \\ Davis, CA 95616, USA \\ ${ }^{2}$ Swedish University of Agricultural Sciences, Department of Rural Development Studies, \\ Box 7005, SE-750 07, Uppsala, Sweden
}

\begin{abstract}
The importance of edible wild plants may be traced to antiquity but systematic studies are recent. Anthropologists, botanists, ecologists, food scientists, geographers, nutritionists, physicians and sociologists have investigated cultural aspects and nutrient composition of edible species. Important contributions to the diet from edible wild plants are well documented and numerous studies reveal roles played by 'lesser-known' species when meeting macro- and micronutrient needs of groups at risk, whether infants and children, pregnant and/or lactating women, or the elderly. The literature is vast and scattered but information on the macroand micronutrient content of wild plants and their importance to the human diet appear in five kinds of publications: cultural works by social scientists, descriptions and inventories by botanists, dietary assessment studies by nutritionists, intervention programmes managed by epidemiologists and physicians, and composition data generally conducted by food scientists and chemists. Many macro- and micronutrient-dense wild species deserve greater attention but lack of adequate nutrient databases, whether by region or nation, limit educational efforts to improve diets in many Third World areas. Limited and uneven compositional data generally reflect factors of cost and personal interest in key nutrients. Whilst edible wild plants are regularly deprecated by policy makers and considered to be the 'weeds of agriculture', it would be tragic if this led to loss of ability to identify and consume these important available species.
\end{abstract}

Ethnobotany: Macronutrients: Micronutrients: Nutritional anthropology: Wild plants

'As there is a plenty of common and French sorrel; lamb's quarters, and water cresses, growing about camp; and as these vegetables are very conducive to health, and tend to prevent the scurvy and all putrid disorders ... the General recommends to the soldiers the constant use of them, as they make an agreeable salad, and have the most salutary effect. The regimental officer of the day [is] to send to gather them every morning, and have them distributed among the men.'

Washington (1777)

*Corresponding author: Dr Louis E. Grivetti, fax +1 530752 8966, email legrivetti@ucdavis.edu 


\section{Introduction}

Throughout history, edible wild plants have sustained human populations in each of the inhabited continents. The agricultural revolution that began more than 10000 years ago created a dramatic shift in the human food supply (Isaac, 1970; Heiser, 1973; Grivetti, 1980). One result was a significant reduction in dietary diversity. As humans focused more on domesticated cultivars and gave less attention to wild species, plants that once offered important flavour and texture satisfaction and supplied essential nutrients to the diet declined in popularity. As humans changed, economically and technologically from hunter-gatherer encampments to settlements, and ultimately to urban living, diets changed significantly in two ways. First, human food patterns reflected increasing intake of fewer domesticated plant staples, and second, edible wild species that once sustained health and nutritional status began to be reduced, and then eliminated from the diet (Grivetti, 1976, 1978, 1981).

In recent centuries humans have focused on relatively few plant species with the result that $80 \%$ of total dietary energy intake, globally, is obtained from twelve domesticated species: eight cereals (barley, maize, millet, rice, rye, sorghum, sugar cane and wheat) and four tubers (cassava, potato, sweet potato and yam). This focus on few cultivars poses two significant problems. First, nutritional reliance on few species, paradoxically, places humans at evolutionary risk as seen if a cereal-specific rust or smut evolved that attacked these critical foodstuffs. The result would be global famine of incomprehensible scale and human catastrophe. The second problem is decline in knowledge. By focusing on domesticated cultivars the collective skills needed to identify and prepare wild foods has declined precipitously. Since species that contained energy and micronutrients became peripheral or were abandoned, humans sometimes have starved in the midst of 'wild food plenty' (Grivetti, 1978).

The purpose of the present review is not to urge a 'return to the land', or to suggest that use of edible wild species is the key to solving the world food crisis. We will present the argument, however, that wild species continue to provide important energy and micronutrient needs during drought and social, political unrest. We will document and sample the vast botanicalnutritional literature on edible wild plants to demonstrate the value of these species in meeting dietary requirements globally. Our intent is not to be inclusive or exhaustive, since numerous publications provide detailed knowledge of wild plant use in specific geographical locations, whether Africa (Hendrick, 1919; Uphof, 1968; Usher, 1974; Tanaka, 1976), Asia (Terra, 1966; Oomen \& Grubben, 1978), or the Americas (Bukason, 1930; Harris \& Munsell, 1950; Sauer, 1950). Instead, we will consider how research has documented the important, critical roles wild plants play in maintaining the nutritional quality of traditional diets.

\section{Themes and problems in edible wild plant research}

It is appropriate to briefly consider several themes that characterize edible wild plant research.

\section{Historical studies}

Human consumption of wild plants has been documented from antiquity into the common era. Dietary use of wild fruits, nuts, seeds and leaves appear in numerous records from ancient Egypt (Darby et al. 1977), Greece (Athenaeus, 1927-1942), Rome (Apicius, 1958), India (Caraka, 1981), China (Simoons, 1991), and the medieval era (Arano, 1976). Spanish conquistadors in North, Central, and South America observed use of edible wild plants as food and 
medicine (Cortéz, 1929; Bernal Diaz, 1956; de la Cruz, 1940; Farfán, 1944; Hernández, 1942 1946). Ingestion of wild plants as food and as medicine lies at the foundation of many traditional healing systems, whether expressed as ancient Mediterranean-style prescriptions (Dioscorides, 1959), or as contemporary patterns exhibited by west African Hausa who consider 'medicine as food-food as medicine' (Etkin \& Ross, 1982; Etkin, 1986, 1994).

Whilst thousands of ancient, medieval, and early modern accounts document wild species and their roles in herbal medicine, the systematic study of edible wild plants is relatively recent. Investigations of edible species have been approached by scholars from many disciplines including anthropology, botany, economics, food science, geography, history, medicine, nutrition and sociology. This diverse literature encompasses botanical classification and systematics (Merrill \& Walker, 1938; Mandiville, 1990; Duke \& Vasquez, 1994); ecology and human-plant interactions (Etkin, 1994; Balick \& Cox, 1996; Cotton, 1996); plant use by age, gender, and social status (Grivetti, 1978, 1979; Lockett, 1999); and dietary use of wild species during civil unrest, war and drought (Valaoras, 1946; Grivetti, 1976).

\section{Salvage ethnobotany and famine foods}

A second body of literature produced during the 1960s by botanists, nutritionists, and social scientists recognized that wild plants commonly served as critical foods during periods just before harvest. Widespread use of these so-called 'famine foods' during the pre-harvest or 'hungry months' has been extensively documented (Miracle, 1961; Brooke, 1967; Hunter, 1967; Annegers, 1973; Ogubu, 1973; Zinyama et al. 1990; Lockett, 1999). As generations passed, the ability to identify 'famine foods' declined precipitously. Once families and societies survived by existing on edible wild plants, but inability to identify sustaining species led to increased malnutrition and famine in certain areas of the world. Attempts to stem this loss have been termed 'salvage ethnobotany' by researchers who attempt to identify famine foods before this critical knowledge is lost (Grivetti, 1976; Ogle, 1982; Humphry et al. 1993; Lockett, 1999).

\section{Hidden harvest: the edible weeds of agriculture}

The concept 'hidden harvest' is used when wild plant foods are studied within agricultural systems to understand their cultural, ecological and nutritional roles in local and regional food security (Scoones et al. 1992). Important leaders in this effort are scientists associated with the International Institute for Environment and Development (IIED), the Swedish International Development Authority (SIDA), and the World Wildlife Fund (WWF), especially the Conservation Policy Division. These scientists have drawn two notable conclusions: that wild foods are part of local and regional agriculture and food procurement systems, and wild species are important genetic resources in global efforts to maintain biodiversity.

\section{Problems in wild plant research}

Three problems must be addressed by researchers interested in edible wild plants. First, how to solve questions of identification and comparison of plant use at global, continental and/or regional, and local scales. Given the hundreds of thousands of edible wild species, global compendia, by definition, present data on relatively few species and in limited depth (Hendrick, 1919; Uphof, 1968; Usher, 1974; Tanaka, 1976). Still, continental or regional compendia are 
useful starting points when investigating edible species for Africa (Dalziel, 1937; Fox, 1966; Irvine, 1948a,b, 1952), Asia (Merrill \& Walker, 1938; Raies, 1980), the Americas (Lundell, 1937; Godshall, 1942; Williams, 1981), or Europe (Couplan, 1983). Other works, in turn, are more narrowly focused on geographical sub-regions such as the tropics (Anderson, 1993; Duke \& Vasquez, 1994), the semi-arid Sahel (von Maydell, 1990), and desert zones (Al-Eiswi \& Takruri, 1989; Bhandari, 1978; Nabhan, 1985). Most work, however, has been conducted among traditional societies or communities, for example, the baTlokwa of eastern Botswana (Grivetti, 1976), highland and lowland Swazi of Swaziland (Ogle, 1982), or the Seri Indians of Sonora, Mexico (Felger \& Moser, 1976).

The second problem is that most research is conducted in professional isolation. Social scientists, whether anthropologists, economists, geographers or sociologists, have conducted significant research on edible species but few of these studies contain quantifiable data that document dietary intake, energy, or micronutrient contributions to the diet. Conversely, publications by biochemists, chemists, food scientists and nutritionists focus on proximate analysis and micronutrient content, and only infrequently contain cultural-ecological or economic data on important species.

The third problem is technical and related to inconsistent project design, diversified methods, and differences related to implementation of field and laboratory studies. The literature on edible wild species is complicated by decisions to use widely different field and laboratory methods that makes study comparisons difficult. Numerous techniques are used to collect, transport and preserve botanical specimens, methods that either preserve or destroy micronutrients. Further, considerable differences exist in techniques used to gather ethnographic data on use of edible species, as well as alternative methods to determine micronutrient composition. Two recent publications (Blum et al. 1997; Khunlein \& Pelto, 1997) have helped to standardize field and laboratory methods. The first describes a step-by-step series of techniques useful to field collectors and laboratory scientists, while the second provides five case studies where the techniques have been tested (China, India, Niger, Peru, and the Philippines). Although both publications focus on field and laboratory assessment of sources for vitamin A, they contain useful information for a wide application of nutrients and micronutrients as well.

One solution to problems of scale, professional isolation and methodology, has been multidisciplinary studies. Since the late 1950 s invitations to participate in multi-disciplinary research have been extended by nutritionists and physicians to anthropologists, geographers and sociologists to solve health and nutrition-related problems. Perhaps the most important multidisciplinary conference and exchange amongst social and biological-medical scientists took place in 1960 at Cuernacavaca, Mexico, where anthropologists, nutritionists and physicians discussed integrative ways to improve rural health (Burgess \& Dean, 1962; Harris, 1962). Whilst collaborative efforts between botanists, ethnographers and laboratory scientists are rare, exceptions can be documented (Kuhnlein et al. 1979; Ogle, 1982; Kuhnlein, 1986, 1989; Smith et al. 1995, 1996; Glew et al. 1998; Sena et al. 1998).

\section{General sources and compilations}

Interrelationships between domesticated and wild species have long attracted botanists and social scientists (Anderson, 1952). At first inspection it appears easy to distinguish wild from domesticated, cultivated from uncultivated, dietary from non-dietary species. On close examination, however, these semantic, taxonomic boundaries are blurred: wild plants are cultivated; medicinal plants are ingested. During the 1960s and 1970s researchers suggested that 
substantial economic and nutritional gains could be achieved by increasing dietary utilization of edible wild plants (Pirie, 1962, 1969a,b; Nietschmann, 1971; von Reis, 1973; Robson, 1976; National Research Council/National Academy of Sciences, 1975, 1979; Wilkes, 1977; Doughty, 1979a,b). Research conducted during the 1970s and 1980s revealed four primary conclusions regarding the nutritional value of edible wild plants:

1. Despite numerous publications that identified important edible wild plants used in North, Central, and South America and the Caribbean, Africa, Asia and Australia, and Europe, data have not been collected systematically and no region has been thoroughly examined;

2. Many traditional, rural agricultural societies rely heavily on edible wild plants to provide important energy and micronutrients throughout the year. Such species play critical roles during periods of drought or civil unrest, and knowledge of these species may be the most important determinant whether or not individuals or families maintain nutritional quality, become malnourished, or succumb;

3. The nutritional composition of most edible wild plants is not known, therefore, educational or policy decisions regarding recommendations for use cannot be made easily;

4. Wild plants commonly serve multiple functions, for example, dye, fibre, food, medicine and oil (Grivetti \& Ogle, 1980a,b,c).

Whilst large-scale agriculture in the late 20th and early 21 st centuries continues to focus on major crops, scholars have called for a better understanding of the so-called 'edible weeds of agriculture' that provide essential nutrients to traditional diets. It is to these wild species and their composition that we now turn.

\section{Wild plants: meeting micronutrient needs}

\section{Sources of information}

Researchers will find nutrient and micronutrient data in five types of sources: (1) Cultural investigations: publications by anthropologists, geographers, historians, and sociologists sometimes contain food pattern data on use of edible wild plants with information on selection, preparation, storage and distribution by sex and age, or by risk group (infants-children, pregnant-lactating women, elderly, refugees); (2) Description and inventory: botanical inventories of locally available species, sometimes contain food and medicinal data; (3) Dietary assessment studies: publications by nutritionists, nutritional anthropologists and nutritional geographers sometimes focus on wild plant food use at the household, aggregate level of analysis, and contain compositional data; (4) Intervention studies: research by nutritionists and physicians that documents how increased use of edible wild species can improve the nutritional status of individuals and groups; (5) Composition reports: publications by biochemists, chemists and nutritionists on proximate analysis, mineral and selected vitamin data, but usually a select number of nutrients of specific interest to the researchers.

Regardless of category, few studies integrate botanical-ecological, cultural-social, with nutrient-micronutrient composition.

\section{Cultural studies}

Interest in the use of edible wild plants by anthropologists may be traced to the pioneering work of Audrey Richards, considered the founder of the field of nutritional anthropology. Her classic studies among the Bemba of Northern Rhodesia (now Zambia) documented the important role 
of wild species in traditional diets (Richards, 1939). A second classic paper, published more than 50 years ago, also challenged prevailing views regarding poverty and food intake, disease and environmental setting, and how an impoverished, traditional society, the Otomí, balanced its diet using edible wild plants (Anderson et al. 1946).

At the time of survey (field work was conducted in 1943) the Otomí were an economically deprived indigenous Native American society living in the Mezquital Valley, north of Mexico City. The Otomí diet was characterized by use of numerous edible wild plants, identified by the American and Mexican scientists as 'weeds'. Despite poverty and an unsanitary environmental setting, the Otomí were well nourished. The Otomí ate relatively few foods and consumption of meat, dairy products, fruits and vegetables was limited. Still, residents of the Mezquital Valley did not exhibit clinical signs of vitamin A deficiency, pellagra, scurvy or rickets. The research team concluded: '[Any] attempts at [dietary] change would be a mistake until [Otomí] economic and social conditions can be improved and something better substituted.' The key to Otomí survival was imbedded in Anderson's text (Anderson et al. 1946): 'Almost every conceivably edible plant, including many of the cacti, are used as food. Many [of these] grow without cultivation during the rainy season, and by most [Americans] would be considered as weeds.' While maize and beans presented a balanced protein intake through complementary amino acids, pulqué (a fermented beverage prepared from the root of the maguey (Agave spp.)) provided B-complex vitamins, the Otomí use of chilies and edible wild plants allowed maintenance of quality nutritional status in this semi-arid land (Anderson et al. 1946; Grivetti, 1999).

The field of cultural ecology that emerged in the post World War II era attracted numerous researchers, both anthropologists and geographers, to ethnobotany and the role of edible wild plants in traditional diets, as shown by studies on the Tarahumara Indians of northern Mexico (Pennington, 1959), use of domesticated and bush foods by the Bayano Cuna Indians of Panama (Bennett, 1962), wild plant use by Sandawe hunters of eastern Africa (Newman, 1968, 1970, 1975), and subsistence ecology of Miskito Indians of Nicaragua (Nietschmann, 1970).

\section{Descriptive works and inventories}

Species inventories with data on dietary or therapeutic uses and micronutrient composition represent a common type of edible wild plant research study. Such efforts usually draw attention to a vast number of local foods often neglected in agricultural studies or dietary investigations. In many geographical regions of the world species inventories are a necessary starting point for more specific dietary and nutritional status research. Some studies of this type provide details on local knowledge and use of wild food plants, important data for understanding the diversity of foods available in specific ecological settings.

A recent inventory of over 600 edible wild vegetables in Vietnam, for example, contained proximate analysis and a suite of mineral and vitamin data for sixty of the more prominent species (Duc, 1988). Other examples include an inventory of edible species common to the semi-arid region of the Sahel in western Africa, where over 800 edible wild plants were identified that made important, critical contributions to mineral and vitamin intakes (Becker, 1983, 1986). Another inventory, which included micronutrient data on 280 Korean wild herbs and vegetables used as food and medicine, reported significant values for carotenoids, vitamin C, and for Ca (Kim \& Oh, 1996), and a compilation of 241 edible wild foods in Zambia presented proximate analysis and mineral values for $\mathrm{Ca}, \mathrm{Fe}$, and P (Malaisse \& Parent, 1985).

From the point of micronutrient nutrition, however, the use of inventories is usually limited unless the descriptive, ecological and systematic data are combined with dietary assessments on 
current consumption. Without this linkage, inventories seldom permit an understanding of the role certain species play in overall micronutrient intake.

\section{Dietary assessment studies}

The nutritional anthropologist Ann Fleuret conducted field work in Tanzania in the 1970s and stated that 'nutrition studies have not seriously considered the role of wild plants in local diets' (Fleuret, 1979). While her comments still apply in 2000, dietary assessment studies completed since her perceptive comment illustrate that wild plants provide important nutrients to infants and children, pregnant and lactating women, the elderly, and indigenous societies globally.

In a study conducted in an isolated Australian Aboriginal community, researchers found extensive use of edible wild foods and essentially no malnutrition (O'Dea et al. 1988). In Bangladesh dietary patterns of women and young children were balanced using dark green leaves as major sources for pro-vitamin A, and the authors concluded that traditional diets, high in edible wild plants, should be protected and promoted (Zeitlin et al. 1992). Analysis of national household data in Brazil revealed that wild fruits had high carotenoid and vitamin A values, but were ignored in nutrition education (Shrimpton, 1989). A study conducted in Papua New Guinea revealed that edible wild plants were nutritionally significant in the local diet and were important sources for Fe intake (Hongo et al. 1989).

A number of studies of this type have been conducted in Africa. In the Gambia, edible wild plants were important during pregnancy and lactation, especially leaf sauces prepared from edible species, and researchers found no evidence of vitamin A deficiency (Villard \& Bates, 1987). In Mali, wild foods were critically important to diet in both rural and urban settings (Nordeide et al. 1994, 1996). In eastern Niger, more than eighty edible wild species were regularly used by $93 \%$ of households and contributed substantial amounts of $\mathrm{Cu}, \mathrm{Fe}, \mathrm{Mg}$, and $\mathrm{Zn}$ to the diet. Further, these plants were frequently sold for extra income (Humphrey et al. 1993). Swaziland has been the focus of research on edible wild plants for more than 50 years, and edible wild fruits and vegetables are commonly eaten throughout the year and contribute significant amounts of $\mathrm{Fe}$, carotenoids, and vitamin $\mathrm{C}$ to the diets of children and adults (Beemer, 1939; Jones, 1963; Ogle \& Grivetti, 1985a,b,c,d; Huss-Ashmore \& Curry, 1991).

\section{Intervention studies}

Several intervention studies that considered wild food plants have been published. In the Gambia, mango and palm oil were identified as critical foods in maintaining carotenoid A intakes and were used to augment diets during pregnancy and lactation (Bates, 1983). The use of burriti sweets (Mauritia vinifera) as part of a vitamin A supplementation, intervention programme for children was implemented in Brazil (Mariath et al. 1989). A recent health intervention focused on traditional foods among the Nuxalk of Canada to improve diet (Kuhnlein \& Burgess, 1997).

\section{Composition reports}

Composition reports on the micronutrient values of edible wild plants abound in the literature but cultural data on when and how such species are used, as to seasonality or importance during the life cycle, are rarely included. Many studies document high values for minerals and vitamins (Eromosele et al. 1991, 1994; Eromosele \& Eromosele, 1993). While most such studies have nutrient composition as their primary objective, some recent papers have looked beyond 
energy and micronutrient composition to understand antioxidant activity as part of broader research designed to understand protective components of traditional diets (Pepping et al. 1988; Lagouri et al. 1993; Johansson et al. 1997).

\section{Discussion: edible wild plants and micronutrient status}

In her dietary study in the Usumbara mountains, Tanzania, Fleuret (1979) concluded that wild vegetables accounted for over $80 \%$ of all leafy vegetables consumed. Indeed, wild vegetables were the major ingredient in side dishes or condiments to staple foods in $25-43 \%$ of the meals recorded in different villages. In other African nations, for example Swaziland, the majority of rural households in quite different agro-ecological niches used wild vegetables throughout the year, and over 220 species of wild plants added to the diversity of the rural diets (Ogle \& Grivetti, 1985a,b,c,d). In Burkina Faso recent investigations have documented that $20 \%$ of all food items consumed were wild species, and numerous wild plants exhibited higher mineral values than more accessible, cultivated alternatives (Smith et al. 1995, 1996). In a recent study from Tanzania, wild vegetables played central dietary roles, where $49 \%$ of vegetables consumed were from wild sources and they supplied a significant portion of micronutrients to the diet in a geographical region where few animal foods were available (Uiso \& Johns, 1996). In eastern Nigeria, settled Fulani agro-pastoralists used edible wild species high in protein and micronutrients to maintain dietary quality during periods of low rainfall. Further, Fulani use of edible wild species for both food and medicine was critical during drought (Lockett, 1999).

Another consideration is how food selection patterns and dietary composition change through time. This approach is interesting for three reasons. First, insights are gained on trends and patterns on the importance of certain species and their overall contribution to human diet (Kim \& Oh, 1996; Labadarios et al. 1996). Second, a better understanding is obtained of plant diversity, regional and/or local ecology and geography, and associations between culture, key species and diet. Third, the nutrition and health of consumers who use edible wild plants can be identified and evaluated as food patterns change through time (Kuhnlein \& Turner, 1991). These factors are especially critical as longitudinal data relating consumption of wild plant resources and nutrient contribution of wild plants to the overall dietary intake are rare.

\section{Wild plants in infant and child feeding}

During the past decades researchers have suggested that wild plants, especially fruits, are important snack foods for children of different ages (Ogle \& Grivetti, 1985a,b,c,d; Dettwyler, 1986; Campbell, 1987; McGregor, 1995; Lockett, 1999). Some studies contain detailed accounts of wild food intake by children. In one study of edible wild plant consumption in rural Swaziland, the authors identified the role of wild plants reported by school children using a $3 \mathrm{~d}$ food record technique, and compared these data with household interviews in the same villages. There was a high degree of agreement between what children and adults said they ate, and actually consumed, but the most surprising finding was that children sometimes had a greater knowledge of wild plants and consumed more wild fruits than adult members of their families (Ogle \& Grivetti, 1985a,b,c,d).

Direct observation and child-following in rural Kenya provided data on wild fruits eaten by school children where over half the students surveyed ate only wild fruits as snacks during daytime at school. Some children consumed edible wild fruit snacks 3-7 times per d, and 
related that they knew and used more than seventy local wild fruit species. A significant finding was that local terms for fruits did not translate as 'food' and according to Taita food ideology, consumption of edible wild fruits would be seriously underestimated or not identified if standard food surveys developed by nutritionists had been used. Indeed, these wild fruit snack foods were major sources of vitamins and minerals, especially carotenoids and vitamin $\mathrm{C}$ (Fleuret \& Fleuret, 1991).

Still other researchers have focused on the role of wild fruits in supplying micronutrients. In one study conducted in three ecological zones of rural Zimbabwe, wild fruits were often the only types of fruits included in the local diets and were important sources of vitamin C, especially for primary school children (Campbell, 1987). A comparative study of two indigenous highland peoples in Thailand presented a similar finding where pre-school children used more wild foods and had a more diverse diet with higher intakes of vitamin $\mathrm{A}$, vitamin $\mathrm{C}$ and $\mathrm{Fe}$ than adults. These researchers noted that wild fruits often were introduced to infant diets earlier than cultivated vegetables, and that wild fruits were important in providing micronutrients and complementing breast milk during the first years of life (Omori \& Greksa, 1996).

On the other hand, some scholars have noted that certain wild leafy vegetables may be excluded from the diets of children in geographical areas where tradition holds that such foods cannot easily be digested or that they cause diarrheoa (Dettwyler, 1988). This finding, however, is balanced in other world regions as amongst the Hausa of Nigeria, where wild plants are considered as both food and medicine and where many species are consumed for their roles in curing gastrointestinal diseases (Etkin \& Ross, 1982).

These positive reports notwithstanding, published information on the role of wild foods in infant and child feeding is uneven and limited. In part, this is a methodological dilemma. Most commonly, $24 \mathrm{~h}$ recall interviews with mothers have been used by researchers to elicit information on dietary intake amongst children. Use of this method, with its well known weaknesses (Krantzler et al. 1982a,b; Mullen et al. 1984), is especially problematic in studies where key foods may be both seasonal, considered as snacks, or even as non-food items, rather than 'real' foods. Indeed, $24 \mathrm{~h}$ recall techniques will not capture the pattern of consumption of many wild fruits and additional questions on wild plant foods must be asked by field nutritionists to provide more accurate information (Campbell, 1987).

\section{Wild plants during pregnancy and lactation}

Diets during pregnancy and lactation are often controlled and managed by cultural traditions and dietary beliefs as to what is appropriate/encouraged and inappropriate/discouraged/taboo at these times (Finley et al. 1985; Grivetti et al. 1987; Grivetti, 1993). Selection or avoidance of wild plants as food during pregnancy and lactation is especially important in geographical areas where dietary alternatives are scarce because of ecological or economic reasons. Only a few studies focus on this specific period in the nutrition life cycle (Fitzgerald et al. 1992).

In one comprehensive review of food sources for vitamin A, examples of how wild foods may be specifically included or excluded in the diet are presented (i.e. fear of gastric upset or concern that adverse flavours will be passed on to the infant via breast milk) but analysis regarding other nutrients was lacking (Johns et al. 1992). An important example of the potential role of wild plants in pregnancy and lactation is from the Gambia where mangoes, leaf sauces, and small amounts of red-palm oil were key sources of vitamin A in the diets of pregnant and lactating women (Villard \& Bates, 1987). Rural Fulani in eastern Nigeria used edible wild 
plants during pregnancy and lactation because of perceived benefits, especially leaves of Veronia colorate and fruits of Lannea schiniperi (Lockett, 1999).

\section{Lack of good databases}

In earlier reviews, we noted the lack of information on energy and micronutrient composition of dietary wild plants, especially for Africa, and the need for improved nutritional databases to allow quantified evaluations of the local and regional diet (Grivetti et al. 1987). Lack of compositional data continues to be a limiting factor when attempting to evaluate the role of wild food plants in contemporary diets. To cope with this problem a number of researchers have conducted multi-disciplinary studies that combine plant inventory and dietary assessment with chemical analysis to determine better the contributions played by edible wild plant species to micronutrient nutrition (Ogle \& Grivetti, 1985a,b,c,d; Humphry et al. 1993; Nordeide et al. 1994, 1996; Smith et al. 1995, 1996; Glew et al. 1998; Lockett, 1999).

Local food composition tables in many countries suffer from incomplete data on wild foods. Many countries also lack funding to develop local composition tables and must substitute by using regional compilations that may or may not include a significant number of foods consumed locally. Further, micronutrient data in food composition tables often are outdated. Illustrating this problem are data from a recent study of food composition reliability in Thailand where nutrient intakes calculated from local food composition tables were compared with chemical analyses of composite food portions. Table calculations regularly overestimated intakes of some nutrients such as vitamin A and niacin, but seriously underestimated others (Speek et al. 1991). This remains a concern, especially as current research indicates large variations in bioavailability of carotenoids from different plant foods and current conversion factors used in food tables may be too low. It has been shown recently that the standard conversion factor of 6 for dark green leafy vegetables should be 26-27, thus a strong case can be made for the importance of wild fruits and tubers as sources of carotenoids (de Pee \& West, 1996; de Pee et al. 1996, 1998).

Incomplete data and use of outdated values is even greater for edible wild plants than for plant foods in general. As a result, researchers interested in the nutritional roles of wild foods in contemporary diets must make assumptions founded on unreliable tables or must conduct analyses to determine the chemical composition of specific key foods. Selection of nutrients for analysis is dependent on research priorities, personal interest in key nutrients, ease of analysis and availability of laboratory facilities. In the end, cost usually determines which nutrients are investigated.

\section{Conclusions}

We have argued elsewhere that edible wild plants are part of agricultural systems, whether in Africa, Asia, the Americas or Europe, and that agricultural development should not be at the expense of nutritional quality of the human diet where edible wild species play critical roles (Grivetti \& Ogle, 1980a,b,c). Similar views have been stated by others who have suggested that the nutritional quality of diet may decline with agricultural development, unless edible wild species that provide essential micronutrients to the diet are considered part of the total food system (Doughty, 1979a,b). Other researchers have documented that some edible wild plants not only augment the human diet, but that the nutritional content of some wild species is superior in vitamin and mineral content to widely-raised domesticated field crops (Calloway 
et al. 1974; Gilliland, 1986). Indiscriminate attempts to push back forest margins to bring vast regions under cultivation may result in the extinction of species not previously examined for their potential as food or other products (Gade, 1972; Prance \& Elias, 1976; Schultes, 1979; Booth et al. 1992; Ali \& Tsou, 1997).

Edible wild plants are regular components of the diets of millions of people in 1999. As documented in this review, these species provide a broad range of micronutrients and in some geographical areas, reliance upon such species is critical especially during months preceding harvest of domesticated field crops. Such species also play prominent roles in sustaining humans during periods of social unrest and military conflict, as well as during drought and other natural catastrophes.

Literature of the past 50 years has continued to stress the importance of edible wild plants as part of the human diet. Further, these so-called 'lesser species' are commonly dismissed by agricultural planners who stress production of more domesticated field crops. What is needed is a better understanding of traditional farming practices, especially customs that protect and manage wild food resources since farmers regularly diversify their diets by using such plants (Haddad \& Oshaug, 1999). Agriculture is a multi-faceted system that combines cultural, environmental and technological abilities to produce food, and decisions to ignore edible wild plants as part of traditional food systems are short-sighted and potentially disastrous. Loss of ability to recognize edible species in environments subject to erratic rainfall and drought, or during periods when normal food supplies are restricted, is an ongoing process, but one that can be stemmed or reversed.

Why has drought repeatedly led to famine in some arid and semi-arid regions of the world, but not all? Why do certain societies, in fact, thrive during drought? Why did so many residents of urban and rural Greece starve during World War II, but others survived? One answer is that knowledge about how to recognize and utilize available edible wild species was maintained, allowing individuals to forage for sustaining foods even under climatic adversity or socialpolitical unrest.

In 2000, the first year of the 21st century, global agriculture focuses on few cultivars, at the expense of edible wild species. The botanical, nutritional and social science literature clearly documents the use of such plants in providing important micronutrients and energy under a broad range of conditions. However, some researchers and health professionals interested in traditional medicines frequently neglect the important roles of wild foods in traditional healthcare systems and focus only on bioactive substances and medicinals. This approach is all the more unusual since many species are both medicine and food. It would be tragic if in the rush to become 'modern', humans lost the ability to identify and use species available to them.

\section{References}

Al-Eiswi DM \& Takruri HR (1989) A checklist of wild edible plants in Jordan. Arab Gulf Journal of Scientific Research Part B. Agricultural and Biological Sciences 7, 79-102.

Ali M \& Tsou SCS (1997) Combating micronutrient deficiencies through vegetables. A neglected food frontier in Asia. Food Policy 22, 17-38.

Anderson E (1952) Plants, Man, and Life. Berkeley, CA: University of California Press.

Anderson EF (1993) Plants and People of the Golden Triangle. Ethnobotany of the Hill Tribes of Northern Thailand. Portland, OR: Dioscorides Press.

Anderson R, Calvo J, Serrano G, \& Payne G (1946) A study of the nutritional status and food habits of Otomí Indians in the Mezquital Valley of Mexico. American Journal of Public Health 36, 883-903.

Annegers JF (1973) Seasonal food shortages in West Africa. Ecology of Food and Nutrition 2, 251-257. 
Apicius (1958) The Roman Cookery Book. A Critical Translation of the Art of Cooking, for Use in the Study and the Kitchen [B Flower and E Rosenbaum, translators]. London: George G. Harrap.

Arano LC (1976) Tacuinum Sanitatis. The Medieval Health Handbook. New York, NY: George Braziller.

Athenaeus (1927-1942) The Deipnosophists [CB Gulick, translator]. New York, NY: G. P. Putnam's Sons.

Balick MJ \& Cox PA (1996) Plants, People, and Culture. The Science of Ethnobotany. Scientific American Library Series no. 60. New York, NY: Scientific American Library.

Bates CJ (1983) Vitamin A in Pregnancy and Lactation. Proceedings of the Nutrition Society 42, 65-79.

Becker B (1983) The contribution of wild plants to human nutrition in the Ferlo (Northern Senegal). Agroforestry Systems 1, 257-267.

Becker B (1986) Wild plants for human nutrition in the Sahelian zone. Journal of Arid Environments 11, 61-64

Beemer H (1939) Notes on the diet of the Swazi in the Protectorate. Bantu Studies 13, 199-236.

Bennett CF Jr (1962) The Bayano Cuna Indians, Panama. An ecological study of livelihood and diet. Annals, Association of American Geographers 52, 32-50.

Bernal Diaz del Castillo (1956) The Discovery and Conquest of Mexico. 1717-1521 [AP Maudslay, translator]. New York, NY: Grove Press.

Bhandari MM (1978) Flora of the Indian Desert. Jodhpur: Scientific Publishers.

Blum L, Pelto PJ, Pelto GH \& Kuhnlein HV (1997) Community Assessment of Natural Food Sources of Vitamin A. Guidelines for an Ethnographic Protocol. Boston, MA: International Nutrition Foundation for Developing Countries.

Booth SL, Johns T \& Kuhnlein V (1992) Natural food sources of vitamin A. Food and Nutrition Bulletin 14, 6-19.

Brooke C (1967) Types of food shortages in Tanzania. Geographical Review 57, 333-357.

Bukason SM (1930) The cultivated plants of Mexico, Guatemala, and Columbia. Bulletin of Applied Botany, Genetics, and Plant Breeding Suppl. 47, 470-553.

Burgess A \& Dean RFA (1962) Malnutrition and Food Habits. Report of an International and Interprofessional Conference. London: Tavistock Publications.

Calloway DH, Giauque RD \& Costa FM (1974) The superior mineral content of some American Indian foods in comparison to federally donated counterpart commodities. Ecology of Food and Nutrition 3, 203-211.

Campbell BM (1987) The use of wild plants in Zimbabwe. Economic Botany 41, 375-385.

Caraka (1981) Caraka-Samhita. Agnivesa's Treatise Refined and Annotated by Caraka and Redacted by Drdhabala, vol. 1, Sutrasthana to Indriyasthana. [P Sharma, editor]. Delhi: Chaukambha Orientalia.

Cortéz H (1929) Hernando Cortés. Five Letters, 1519-1526 (Cartas de Relacion) [ED Ross and E Power, editors; JB Morris, translator]. New York, NY: Robert M. McBride and Co.

Cotton CM (1996) Ethnobotany: Principles and Applications. New York, NY: John Wiley \& Sons.

Couplan F (1983) Encyclopedie des plantes comestibles de l'Europe (Encylopaedia of edible European plants). Paris: Debard.

Dalziel JM (1937) The Useful Plants of West Tropical Africa. Being an Appendix to the Flora of West Tropical Africa by J. Hutchinson and J. M. Dalziel. London: Crown Agents for Overseas Governments and Administrations.

Darby WJ, Ghalioungui P \& Grivetti LE (1977) Food. The Gift of Osiris. London: Academic Press.

de la Cruz M (1552) (1940) The Badianus Manuscript (Codex Barberini, Latin 241) Vatican Library. An Aztec Herbal of 1552. [EW Emmart, translator]. Baltimore, MA: The Johns Hopkins Press.

de Pee S \& West EE (1996) Dietary carotenoids and their role in combating vitamin A deficiency. A Review of the Literature. European Journal of Clinical Nutrition 50, S38-S53.

de Pee S, West CE, Muhilal, Karyadi D \& Hautvast JGAJ (1996) Can increased vegetable consumption improve iron status? Food and Nutrition Bulletin 17, 34-36.

de Pee S, West CE, Permaesih D, Martuti S, Muhilal \& Hautvast JG (1998) Orange fruit is more effective than are dark-green, leafy vegetables in increasing serum concentrations of retinol and beta-carotene in school children in Indonesia. American Journal of Clinical Nutrition 68, 1058-1067.

Dettwyler KA (1986) Infant feeding in Mali, West Africa. Variations in belief and practice. Social Science and Medicine 23, 651-664.

Dettwyler KA (1988) Styles of infant feeding. Parental/caretaker control of food consumption in young children. American Anthropologist 91, 696-703.

Dioscorides (1959) The Greek Herbal of Dioscorides [RT Gunther, translator]. New York, NY: Hafner.

Doughty J (1979a) Dangers of reducing the range of food choices in developing countries. Ecology of Food and Nutrition 8, 275-283.

Doughty J (1979b) Decreasing variety of plant foods used in developing countries. Qualitas Plantarum 29, $163-177$.

Duc BM (1988) Study of the nutritive value and utilization of wild vegetables in Viet Nam. In Applied Nutrition. Proceedings of the International Conference on Applied Nutrition, Hanoi, 25-29 April, 1986, pp. 327-333. Hanoi: The National Institute of Nutrition and UNICEF.

Duke JA \& Vasquez R (1994) Amazonian Ethnobotanical Dictionary. Boca Raton, FL: CRC Press.

Eromosele IC \& Eromosele CO (1993) Studies on the chemical composition and physico-chemical properties of seeds of some wild plants. Plant Foods for Human Nutrition 43, 251-258.

Eromosele IC, Eromosele CO, Akintoye AO \& Komolafe TO (1994) Characterization of oils and chemical analyses of the seeds of wild plants. Plant Foods for Human Nutrition 46, 361-365. 
Eromosele IC, Eromosele CO \& Kuzhkuzha DM (1991) Evaluation of mineral elements and ascorbic acid contents in fruits of some wild plants. Plant Foods for Human Nutrition 41, 151-154.

Etkin NL (1986) Plants in Indigenous Medicine and Diet. Biobehavioral Approaches. Bedford Hills, NY: Redgrave Press.

Etkin NL (1994) Eating on the Wild Side. The Pharmacologic, Ecologic, and Social Implications of Using Noncultigens. Tucson, AZ: University of Arizona Press.

Etkin NL \& Ross PJ (1982) Food as medicine and medicine as food. Social Science and Medicine 16, 1559-1573.

Farfán A (1579, 1592) (1944) Tractado Breve de Medicina. Madrid: Ediciones Cultura Hispánica.

Felger R \& Moser MB (1976) Seri Indian food plants. Desert subsistence without agriculture. Ecology of Food and Nutrition 5, 13-27.

Finley DA, Dewey KG, Lonnerdal B \& Grivetti LE (1985) Food choices of vegetarians and non-vegetarians during pregnancy and lactation. Journal of the American Dietetic Association 85, 678-685.

Fitzgerald SL, Gibson RS, Portocarrero L \& Deserrano JQ (1992) Food consumption patterns and dietary diversity of pregnant women living in a peri-urban area of Guatemala City. Ecology of Food and Nutrition 27, 1-15.

Fleuret A (1979) The role of wild foliage plants in the diet. A case study from Lushoto, Tanzania. Ecology of Food and Nutrition 8, 87-93.

Fleuret P \& Fleuret A (1991) Social organization, resource management, and child nutrition in the Taita Hills, Kenya. American Anthropologist 93, 91-114.

Fox FW (1966) Studies on the Chemical Composition of Foods Commonly Used in Southern Africa. Johannesburg: South African Institute for Medical Research.

Gade DW (1972) South American lupin and the process of decline in the World Cultigen Inventory. Journal d'Agriculture Tropicale et de Botanique Appliquée 19, 87-92.

Gilliland L (1986) Proximate analysis and mineral composition of traditional California Native American foods. MSc Thesis, University of California, Davis.

Glew RH, VanderJagt DJ, Lockett C, Grivetti LE, Smith GC, Pastuszyn A \& Millson M (1998) Amino acid, fatty acid, and mineral composition of 24 indigenous plants of Burkina Faso. Journal of Food Composition and Analysis 10, $205-217$.

Godshall AB (1942) Edible, Poisonous, and Medicinal Fruits of Central America. Panama Canal, Panama: privately published.

Grivetti LE (1976) Dietary resources and social aspects of food use in a Tswana tribe. PhD Thesis, University of California, Davis.

Grivetti LE (1978) Nutritional success in a semi-arid land. Examination of Tswana agro-pastoralists of the Eastern Kalahari, Botswana. American Journal of Clinical Nutrition 31, 1204-1220.

Grivetti LE (1979) Kalahari agro-pastoral-hunter-gatherers. The Tswana example. Ecology of Food and Nutrition 7 , $235-256$.

Grivetti LE (1980) Goat kraal gardens and plant domestication. Thoughts on ancient and modern food production. Ecology of Food and Nutrition 10, 5-7.

Grivetti LE (1981) Cultural nutrition. Anthropological and geographical themes. Annual Review of Nutrition 1, 47-68.

Grivetti LE (1993) Nutritional anthropology. An integrated approach to pregnancy and delivery. In Modern Nutrition in Health and Disease, 8th ed., pp. 1517-1525. Philadelphia, PA: Lea and Febiger.

Grivetti LE (1999) Sound nutrition in the midst of poverty. The Otomí revisited. In Proceedings, Cultural and Historical Aspects of Foods. Yesterday, Today, and Tomorrow, pp. 90-98 [MW Kelsey and Z-A Holmes, editors]. Corvallis, OR: Nutrition and Food Management College of Home Economics and Education, Oregon State University.

Grivetti LE, Frentzel CJ, Ginsberg KE, Howell KL \& Ogle BM (1987) Bush foods and edible weeds of agriculture. Perspectives on dietary use of wild plants in Africa; their role in maintaining human nutritional status, and implications for agricultural development. In Health and Disease in Tropical Africa. Geographical and Medical Viewpoints, pp. 51-81 [R Akhtar, editor]. London: Harwood.

Grivetti LE \& Ogle BM (1980a) Agricultural Development. Present and Potential Role of Edible Wild Plants. Part 1. Central and South America and the Caribbean. Report to the Department of State, Agency for International Development. Washington, D.C.: USAID.

Grivetti LE \& Ogle BM (1980b) Agricultural Development. Present and Potential Role of Edible Wild Plants. Part 2. Sub-Saharan Africa. Report to the Department of State, Agency for International Development. Washington, D.C.: USAID.

Grivetti LE \& Ogle BM (1980c) Agricultural Development. Present and Potential Role of Edible Wild Plants. Part 3. India, East Asia, Southeast Asia, Oceania. Report to the Department of State, Agency for International Development. Washington, D.C.: USAID.

Haddad L \& Oshaug A (1999) How does the human rights perspective help to shape the food and nutrition policy research agenda? Food Policy 23, 329-345.

Harris R (1962) Influences of culture on man's diet. Archives of Environmental Health 5, 144-152.

Harris RS \& Munsell HE (1950) Edible plants of Central America. Journal of Home Economics 42, 629-631.

Heiser CB (1973) Seed to Civilization. The Story of Man's Food. San Francisco, CA: W.H. Freeman.

Hendrick UP (1919) Sturtevant's Notes on Edible Plants. Albany, NY: J. B. Lyon State Printer. 
Hernández F (1577) (1942-1946) Historia de las Plantas de la Nueva España. [I Ochoterena, editor]. México City: Imprenta Universitaria.

Hongo T, Suzuki T, Ohtsuka R, Kawabe T, Inaoka T \& Akimichi T (1989) Element intake of the Gidra in lowland Papua. Inter-village variation and the comparison with contemporary levels in developed countries. Ecology of Food and Nutrition 23, 293-309.

Humphry CM, Clegg MS, Keen CL \& Grivetti LE (1993) Food diversity and drought survival. The Hausa example. International Journal of Food Sciences and Nutrition 44, 1-16.

Hunter JM (1967) Seasonal hunger in a part of the West African savanna. A survey of body weights in Nangodi, Northeast Ghana. Transactions, Institute of British Geographers 41, 167-185.

Huss-Ashmore R \& Curry JJ (1991) Diet, nutrition, and agricultural development in Swaziland. Part 2. Patterns of food consumption. Ecology of Food and Nutrition 26, 167-185.

Irvine FR (1948a) The indigenous food plants of West African peoples. Part 1. Journal of the New York Botanical Garden No. 586, 49, $22-236$.

Irvine FR (1948b) The indigenous food plants of West African peoples. Part 2. Journal of the New York Botanical Garden No. 587, 49, 254-267.

Irvine FR (1952) Supplementary and emergency food plants of West Africa. Economic Botany 6, 23-40.

Isaac E (1970) Geography of Domestication. Englewood Cliffs, NJ: Prentice-Hall.

Johansson A, Laakso P \& Kallio H (1997) Characterization of seed oils of wild, edible Finnish berries. Zeitschrift für Lebensmittel, Untersuchung und Forschung 204, 300-307.

Johns T, Booth SL \& Kuhnlein HV (1992) Factors influencing vitamin A intake and programmes to improve vitamin A status. Food and Nutrition Bulletin 14, 20-33.

Jones SM (1963) A Study of Swazi Nutrition. Report of the Swaziland Nutrition Survey 1961-62 for the Swaziland Administration. Durban, South Africa: Institute for Social Research, University of Natal.

Kim SH \& Oh S-Y (1996) Cultural and nutritional aspects of traditional Korean diet. World Review of Nutrition and Dietetics 79, 109-132.

Krantzler NJ, Mullen BJ, Comstock EM, Holden CA, Schutz HG, Grivetti LE \& Meiselman HL (1982a) Methods of food intake assessment. An annotated bibliography. Journal of Nutrition Education 14, 108-119.

Krantzler NJ, Mullen BJ, Schutz HG, Grivetti LE, Holden CA \& Meiselman HL (1982b) Validity of telephoned diet recalls and records for assessment of individual food intake. American Journal of Clinical Nutrition 36, $1234-1242$.

Kuhnlein HV (1986) Food sample collection for nutrient analyses in ethnobiological studies. Journal of Ethnobiology 6, $19-25$.

Kuhnlein HV (1989) Factors influencing use of traditional foods among the Nuxalk people. Journal of the Canadian Dietetic Association 50, $102-108$.

Kuhnlein HV \& Burgess S (1997) Improved retinol, ferritin and folate status in Nuxalk teenagers and adults after a health promotion programme. Food and Nutrition Bulletin 18, 202-210.

Kuhnlein HV, Calloway DH \& Harland BH (1979) Composition of traditional Hopi foods. Journal of the American Dietetic Association 75, 37-41.

Kuhnlein HV \& Pelto GH (1997) Culture, Environment, and Food to Prevent Vitamin A Deficiency. Boston, MA: International Nutrition Foundation for Developing Countries.

Kuhnlein HV \& Turner NJ (1991) Traditional Plant Foods of Canadian Indigenous Peoples. Nutrition, Botany, and Use. Philadelphia, PA: Gordon and Breach.

Labadarios D, Walker ARP, Blaauw R \& Walker BF (1996) Traditional diets and meal patterns in South Africa. World Review of Nutrition and Dietetics 79, 70-108.

Lagouri V, Blekas G, Tsimidou M \& Kokkini S (1993) Composition and antioxidant activity of essential oils from oregano plants grown wild in Greece. Zeitschrift für Lebensmittel, Untersuchung and Forschung 197, 20-23.

Lockett CT (1999) Nutritional consequences of food-related behaviors during drought and chemical composition of edible wild plants consumed by groups most vulnerable during the dry season. A study of the rural Fulani of northeast Nigeria. PhD Thesis, University of California, Davis.

Lundell CL (1937) The Vegetation of Petén. With an Appendix. Studies of Mexican and Central American Plants, vol. 1, publication no. 478. Washington, D.C.: Carnegie Institute of Washington.

McGregor J (1995) Gathered produce in Zimbabwe's communal areas changing resource availability and use. Ecology of Food and Nutrition 33, $163-193$.

Malaisse F \& Parent G (1985) Edible wild vegetable products in the Zambezian woodland area. A nutritional and ecological approach. Ecology of Food and Nutrition 18, 43-82.

Mandaville JP (1990) Flora of Eastern Saudi Arabia. London: Kegan Paul and Riyadh: National Commission for Wildlife Conservation and Development.

Mariath HGR, Lima MCC \& Santos LMP (1989) Vitamin A activity of Burriti (Mauritia vinifera Mart.) and its effectiveness in the treatment and prevention of xeropthalmia. American Journal of Clinical Nutrition 49, 849-853.

Merrill ED \& Walker EH (1938) A Bibliography of Eastern Asiatic Botany. Jamaica Plain, MA: Arnold Arboretum of Harvard University.

Miracle MP (1961) Seasonal hunger. A vague concept and an unexplored problem. Bulletin de l'Institut Français d'Afrique Noire 23, 273-283.

Mullen BJ, Krantzler NJ, Grivetti LE, Schutz HG \& Meiselman HL (1984) Validity of a food frequency questionnaire for the determination of individual food intake. American Journal of Clinical Nutrition 39, 136-143. 
Nabhan GP (1985) Gathering the Desert. Tucson, AZ: University of Arizona Press.

National Research Council/National Academy of Sciences (1975) Underexploited Tropical Plants with Promising Economic Value. Washington, D.C.: National Research Council/National Academy of Sciences.

National Research Council/National Academy of Sciences (1979) Tropical Legumes. Resources for the Future. Washington, D.C.: National Research Council/National Academy of Sciences.

Newman JL (1968) Geography and subsistence change among the Sandawe. PhD Thesis. University of Minnesota.

Newman JL (1970) The Ecological Basis for Subsistence Change among the Sandawe of Tanzania. Washington, D.C.: National Academy of Sciences.

Newman JL (1975) Dimensions of Sandawe diet. Ecology of Food and Nutrition 4, 33-39.

Nietschmann BQ (1970) Between land and water. The subsistence ecology of the Miskito indians, eastern Nicaragua. PhD Thesis. University of Wisconsin, Madison.

Nietschmann BQ (1971) The study of indigenous food production systems. Mere subsistence or merrily subsisting? Revista Geographica 74, 83-99.

Nordeide MB, Hatloy A, Folling M, Lied E \& Oshaug A (1996) Nutrient composition and nutritional importance of green leaves and wild food resources in an agricultural district, Koutiala, in Southern Mali. International Journal of Food Sciences and Nutrition 47, 455-468.

Nordeide MB, Holm H \& Oshaug A (1994) Nutrient composition and protein quality of wild gathered foods from Mali. International Journal of Food Sciences and Nutrition 45, 275-286.

O'Dea K, White NG \& Sinclair AJ (1988) An investigation of nutrition-related risk factors in an isolated Aboriginal community in northern Australia. Advantages of a traditionally-orientated life-style. Medical Journal of Australia 148, $177-180$

Ogle BM (1982) Dietary utilization of wild plant resources in four ecological zones of rural Swaziland. MSc Thesis. University of California, Davis.

Ogle BM \& Grivetti LE (1985a) Legacy of the chameleon. Edible wild plants in the Kingdom of Swaziland, Southern Africa. A cultural, ecological, nutritional study. Part 1. Introduction, objectives, methods, Swazi culture, landscape, and diet. Ecology of Food and Nutrition 16, 193-208.

Ogle BM \& Grivetti LE (1985b) Legacy of the chameleon. Edible wild plants in the Kingdom of Swaziland, Southern Africa. A cultural, ecological, nutritional study. Part 2. Demographics, species availability and dietary use, analysis by ecological zone. Ecology of Food and Nutrition 17, 1-30.

Ogle BM \& Grivetti LE (1985c) Legacy of the chameleon. Edible wild plants in the Kingdom of Swaziland, Southern Africa. A cultural, ecological, nutritional Study. Part 3. Cultural and ecological analysis. Ecology of Food and Nutrition 17, 31-40.

Ogle BM \& Grivetti LE (1985d) Legacy of the chameleon. Edible wild plants in the Kingdom of Swaziland, Southern Africa. A cultural, ecological, nutritional study. Part 4. Nutritional analysis and conclusions. Ecology of Food and Nutrition 17, 41-64.

Ogubu JO (1973) Seasonal hunger in tropical Africa as a cultural phenomenon. The Onicha Ibo of Nigeria and Chakaka Poka of Malawi examples. Africa 43, 317-332.

Omori K \& Greksa LP (1996) Dietary patterns and dietary adequacy of Highland Pwo and Sgaw Karen of Northeast Thailand. Ecology of Food and Nutrition 35, 219-235.

Oomen HAPC \& Grubben GJH (1978) Tropical Leaf Vegetables in Human Nutrition. Amsterdam: Koninklikj Instituut voor de Tropen.

Pennington C (1959) The material culture of the Tarahumara and their environment. PhD Thesis. University of California, Berkeley.

Pepping F, Vencken CMJ \& West CE (1988) Retinol and carotene content of foods consumed in East Africa determined by high performance liquid chromatography. Journal of the Science of Food and Agriculture 45, 359-371.

Pirie NW (1962) Indigenous foods. Advancement of Science 18, 467-475.

Pirie NW (1969a) Food Resources. Conventional and Novel. London: Penguin Books.

Pirie NW (1969b) Plants as sources of unconventional protein foods. In All-Congress Symposium. World Food Supply, vol. 11. International Botanical Congress, Seattle, Washington, August 28th, 1969.

Prance GT \& Elias TS (1977) Extinction is Forever. Threatened and Endangered Species of Plants in the Americas and Their Significance in Ecosystems Today and in the Future. Proceedings of a Symposium, May 11-13, 1976, Bronx, New York. New York, NY: The New York Botanical Garden.

Raies RR (1980) Checklist of Economic Plants in Asia. Laguna, Philippines: Agricultural Information Bank for Asia. Richards AI (1939) Land, Labour and Diet in Northern Rhodesia. An Economic Study of the Bemba Tribe. London: International Institute of African Languages and Cultures.

Robson JRK (1976) Changing food habits in developing countries. Ecology of Food and Nutrition 4, 251-256.

Sauer JD (1950) The Grain Amaranths. A survey of their history and classification. Annals of the Missouri Botanical Gardens 37, 561-632.

Schultes RE (1979) The Amazonia as a source of new economic plants. Economic Botany 33, 259-266.

Scoones I, Melnyk M \& Pretty JN (1992) The Hidden Harvest. Wild Foods and Agricultural Systems. A Literature Review and Annotated Bibliography. London: Sustainable Agriculture Programme, International Institute for Environment and Development. 
Sena LP, VanderJagt DJ, Rivera C, Tsin AT, Muhamadu I, Mahamadou O, Millson M, Pastuszyn A \& Glew RH (1998) Analysis of nutritional components of eight famine foods of the Republic of Niger. Plant Foods for Human Nutrition 52, $17-30$.

Shrimpton R (1989) Vitamin A deficiency in Brazil. Perspectives for food production oriented interventions. Ecology of Food and Nutrition 23, $261-271$.

Simoons FJ (1991) Food in China. A Cultural and Historical Inquiry. Boca Raton, FL: CRC Press.

Smith GC, Clegg MS, Keen CL \& Grivetti LE (1995) Mineral values of selected plant foods common to Southern Burkina Faso and to Niamey, Niger, West Africa. International Journal of Food Sciences and Nutrition 47, 41-53. Smith GC, Dueker SR, Clifford AJ \& Grivetti LE (1996) Carotenoid values of selected plant foods common to Southern Burkina Faso, West Africa. Ecology of Food and Nutrition 35, 43-58.

Speek AJ, Speeksaichusa S \& Schreurs WHP (1991) Determination of macronutrient and micronutrient levels in Thai foods. An evaluation of the Thai food composition table. Food Chemistry 40, 251-262.

Tanaka T (1976) Tanaka's Cyclopedia of Edible Plants of the World. Tokyo: Keigagu Publishing Company.

Terra GJA (1966) Tropical Vegetables. Communication no. 54e. Department of Agricultural Research of the Royal Tropical Institute. Amsterdam: Royal Tropical Institute.

Uiso FC \& Johns T (1996) Consumption patterns and nutritional contribution of Crotalaria brevidens (mitoo) in Tarime District, Tanzania. Ecology of Food and Nutrition 35, 59-69.

Uphof JCH (1968) Dictionary of Economic Plants, 2nd ed. New York, NY: Stechert-Hafner.

Usher G (1974) A Dictionary of Plants Used by Man. London: Constable.

Valaoras VG (1946) Some effects of famine on the population of Greece. Milbank Fund Quarterly 24, $215-234$.

Villard L \& Bates CJ (1987) Dietary intake of vitamin A precursors by rural Gambian pregnant and lactating women. Human Nutrition 41, 135-145.

von Maydell HJ (1990) Trees and Shrubs of the Sahel. Their Characteristics and Uses. Weikersheim: Verlag Josef Margraf.

von Reis A (1973) Drugs and Foods from Little-Known Plants. Cambridge, MA: Harvard University Press.

Washington G (1777) General Orders. Issued June 9th, 1777, Headquarters, Middle-Brook. National Archives, Washington, D.C.

Wilkes G (1977) Native crops and wild food plants. Ecologist 7, 312-317.

Williams LO (1981) The Useful Plants of Central America. Tegucigalpa, Honduras: Escuela Agrícola Panamericana

Zeitlin MF, Megawangi R, Kramer EM \& Armstrong HC (1992) Mothers' and children's intakes of vitamin A in rural Bangladesh. American Journal of Clinical Nutrition 56, 6136-6147.

Zinyama LM, Matiza T \& Campbell DJ (1990) The use of wild foods during periods of food shortage in rural Zimbabwe. Ecology of Food and Nutrition 24, 251-256. 